\title{
Documenting Spoken and Sung Texts of the Dagaaba of West Africa
}

\author{
ADAMS BODOMO \\ The University of Hong Kong \\ MANOLETE MORA [1] \\ The University of Hong Kong
}

\begin{abstract}
This article discusses a documentation of spoken texts, sung texts, and dances of the Dagaaba, a mainly oral West African cultural group based on actual interdisciplinary linguistic and musicological field research within the group. The importance of this documentation lies in the fact that traditional oral cultures are fast disappearing among some sections of such societies in the face of a ruthless process of globalization. The article outlines the socio-cultural organization of the communities investigated, gives a succinct description of the structure of Dagaare, language of the Dagaaba, and describes the structure of bawaa, their main dance, before analyzing transcriptions of a representative sample of spoken and sung folktales with comments on the thought systems and world-views emanating from these texts.
\end{abstract}

Submitted 2007 February 18; accepted 2007 March 14

KEYWORDS: West Africa song dance story oral culture Dagaare Dagaaba bawaa

\section{INTRODUCTION}

DOCUMENTING cultural elements such as language and music for posterity has always been or ought to be an important aspect of linguistic, musical, and anthropological studies. This is all the more important, because, as is well known, smaller and more rural cultural groups are under threat of extinction from dominant cultures. The primary material for this article is a recording that was done as part of a research project that focused on the language and music of the Dagaare-speaking people of the Republic of Ghana, West Africa (see Figure 1). The main intention of the project is to document songs, proverbs, riddles, spoken and sung folktales, instrumental music, and dance performances, in particular báwáa, in their "natural" contexts. In this article, we briefly describe the location of the fieldwork in the northwestern parts of Ghana, where most Dagaaba live, and its capital city, Accra, where many have settled, in the following section. We then outline the basic structure of the Dagaare language, Dagaare music, and Dagaare dance, especially the báwáa dance, and the musical instruments, before giving concise interpretations and commentaries on the spoken and song texts, which have also been included as liner notes of a CD submitted to UNESCO for dissemination (Mora and Bodomo forthcoming). We conclude the article with a recap of the importance of the need to document more ethnic languages and musics around the world. 


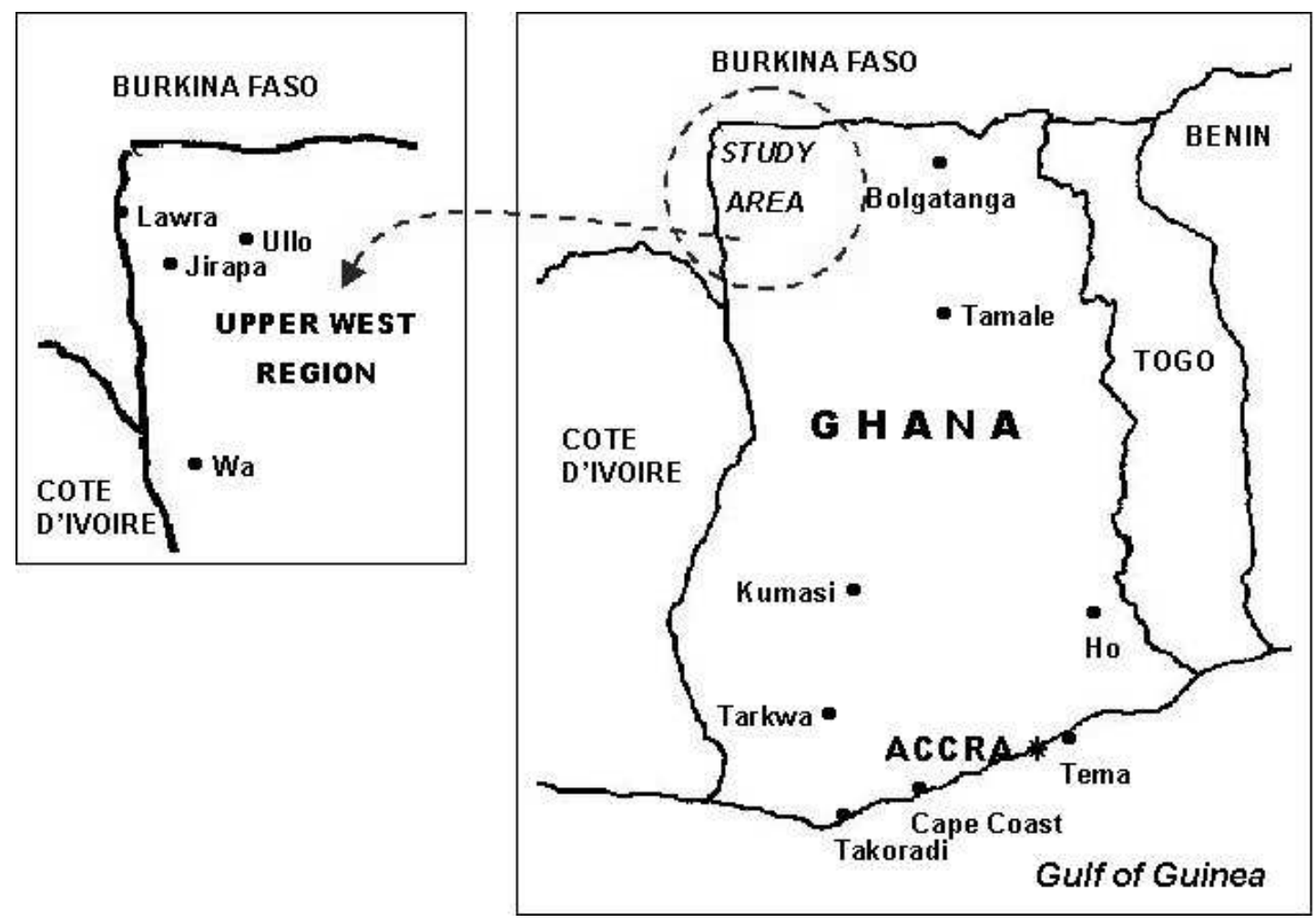

Fig. 1. Map of research site.

\section{THE DAGAARE COMMUNITIES IN KOGRI, ULLO, AND ACCRA}

The Dagaaba live in the northwestern part of Ghana in West Africa. Dagaare, the language of the Dagaaba, is spoken by about 2 million people, mainly in Ghana but also in the neighboring regions of Burkina Faso and the Ivory Coast. Most of the music recorded during the fieldtrip, some of which is contained in a CD submitted to UNESCO world music series (Mora and Bodomo forthcoming), came from the Dagaare rural communities of Kogri and Ullo in northwestern Ghana, though some came from the migrant communities of Accra, the capital of Ghana.

Kogri, located in the Savannah belt between latitudes 10 degrees and 11 degrees north of the equator and longitudes 2 degrees and 3 degrees west of the Greenwich meridian, is one of many villages that comprise the Ullo sub-district in the Jirapa-Lambussie district. This is one of eight districts that form the Upper-West administrative region, which in turn is one of ten administrative regions of Ghana.

Accra, the capital of Ghana, is a flourishing metropolis located on the Gulf of Guinea on the West African coast. In the $17^{\text {th }}$ century, it was a small, coastal village inhabited by the Ga people. Now it is a political and commercial centre of more than two million people from different ethno-linguistic groups, including, the Akan, Ewe, Dagomba, Frafra, and Dagaaba. There are also peoples from other West African nations and beyond. Accra, then, is cosmopolitan and supports a lively and diverse range of popular and traditional musics as the following excerpt illustrates:

Before leaving Accra for the long journey northward to Dagaaba-land Adams, his friend Boniface, and I decided to sample some of the city's music in both uptown hotels and downtown nightspots. In the Golden Tulip Hotel, a band made up of local musicians performed a variety of Caribbean musics including Cuban mambo and son from pre-Revolutionary Cuba. The band was very good and had clearly assimilated the stylistic nuances of Cuban music. The clave was authentic as were the montunos that supported the instrumental improvisations. Unfortunately, the audience, largely tourists from abroad, did not respond to the call to dance. The leader of the band, perhaps in his late 50s, told me that he had been playing this music and various types of Ghanaian popular dance music for many years. 
When the band stopped around midnight, we went downstairs to the jazz bar of the hotel, where some local jazz musicians and a guest singer and piano player from the United States entertained a more appreciative audience. After several sets from the jazz group, Boniface suggested we drive to Adabraka, the nightclub quarter of Accra. Adabraka was a district of ramshackle, single-story, tin-roofed clubs that reverberated with many types of West African urban dance genres from Ghanaian highlife to Zairean kisomba. The music spilled out of the clubs and onto the streets amid the heterogeneous groups of men and women from various parts of Ghana, Zaire, Nigeria, Senegal, Burkina Faso and Togo. Everyone seemed to blend in and accommodate each other's language and music. Though in the Wakiki club there was the occasional, ardent cry for 'more French music', that is, popular music from French-speaking, West Africa. [from Mora's field notes]

Besides Ga, the indigenous language of Accra, and English, the official language of the country, many languages are spoken in Accra. Various migrant groups have established their own communities, social clubs, and organizations to cater for their social and cultural needs. There are frequent displays of traditional culture within these various social groups, in particular, traditional dance groups.

Rural-urban migration is transforming Ghana. Both high and low income earners have moved into the suburbs of Accra to seek opportunities. Migrant communities have established organisations to cater for their particular ethnic, social and cultural needs. There are frequent displays of traditional culture within these various communities throughout Accra. Dagaare immigrants have tended to settle in suburbs like Achimota, Nima, and Russia/Larterbiokoshie.

Among the Dagaare communities in Accra, there are many cultural organisations, though our recordings were made within the Jirapa Area Youth and Development Association (JAYDA). The JAYDA dance group was formed in 1997 by James Amarę and takes particular pride in its performance of báwáa dance, as do other Accra-based Dagaare groups. Indeed, these groups recruit skilled musicians and dancers from the ancestral villages and towns of Dagao, the homeland of the Dagaaba, in order to achieve and maintain positions of distinction. The recruitment of these skilled performers also strengthens the sense of a Dagaare cultural identity.

\section{THE STRUCTURE OF THE DAGAARE LANGUAGE}

One of the objectives of the field research was to obtain a body of music that would serve as a basis for comparative linguistic and musicological analysis. With this in mind, the structure of the Dagaare language and the group to which it belongs, the Mabia languages, are briefly described here along with the main typological features of this group and an explanation of how the linguistic data is transcribed and presented.

Dagaare is a two-toned language of the Mabia subgroup of the branch of the Niger-Congo language of West Africa. (Bodomo 1997, 2000; Anttila and Bodomo 2001). It is spoken by about 2 million people, mainly in Ghana but also in neighbouring regions of West Africa, like Burkina Faso and the Ivory Coast. Phonologically speaking, Dagaare and other Mabia languages, including Moore, Dagbane, Frafra, Kusaal, Mampruli and Buli, are marked by a preponderance of consonants and a scarcity of vowel sounds when compared to Indo-European languages, such as English and French (Bodomo 2004). One distinctive phonological feature is the double articulation of some consonants. These include labio-velar stops like $/ \mathrm{gb} / \mathrm{kp} /$ and $/ \mathrm{ngm} /$. Such features, rare in Indo-European languages, are a common feature in many African languages. The labio-velar and velar sounds are partially complementary, as in the alternate causative/non-causative forms of the verbs / $k u$ ' 'kill' and /kpì/, 'die' in Dagaare. Regular allophones often involve /d/ and /r/, and /g/ and / // across the various languages. There may also be limited cases of free variation as it is between $/ \mathrm{h} / \mathrm{and} / \mathrm{z} /$ in the Dagaare word, hàál zàá, 'all'.

There is the typological feature of vowel harmony in Dagaare and many Mabia languages. Words like kógó ('chair'), biîrí ('children'), and túúrò ('digging') are pronounced with tense or advanced tongue root vowels, while words like kóbś ('bones'), biîrì ('to brew "pito" the second day'), and túúrì ('insulting') are pronounced with lax or unadvanced tongue root vowels. Front rounded vowels, found in languages like French and Norwegian, and back unrounded vowels are absent in these languages, except when phonetically realized in particular environments. 
Syllabic nasality is also a typological feature in these languages. These are realized in some environments, most often as pronouns and particles; as in the case of the Dagaare third person pronoun $/ \mathrm{N} /$ as in $\grave{m} b \hat{a}$, ('my father'), $\grave{n} z \hat{u}$ ('my head') and in the Dagaare particle, $-\not \eta$, which is a cliticized form of the polarity marker, lá.

Dagaare and other Mabia languages primarily have two tonal systems, high and low, (respectively marked by acute and grave diachritics on the sounds with contain them) with cases of downstep in some of the languages. These tones serve to express both lexical and grammatical oppositions as in the Dagaare verbs, dá ('push'), dà ('buy'), and as in the declarative and hortative readings of pronouns e.g., ikúlí lá yîrì or zkúlî yîrì ('He went home' or 'He should go home').

Dagaare, and its group of languages, usually manifest open syllables. Both CV and CVC syllables can be reconstructed, but it is usually possible to insert a final, epenthetic, vowel. Thus, the Dagaare verb 'to leave', may be realized either as bàr or bàrì. There are also dialectal differences with respect to these two forms.

An important typological feature of these languages is the system of noun classes. Noun class manifestation is a common feature for Niger-Congo languages, but while most of these languages use a prefixal pattern, Mabia languages mostly use a system of class suffixes. These are typically based on singular/plural alternations. Most nouns exist in three forms: the root, the singular, and the plural. An example is the Dagaare word for 'woman/wife': pog- (root), pógá (singular), pógbá (plural), with the further vowel assimilation in some dialects to give us pógs and pógb́. In this case the singular/plural affixes are $-a /-b a$. All words that exhibit this pattern are then categorized into one class.

Another important typological feature within Dagaare and its group of languages is verb morphology. In most of these languages there is a regular form of marking perfective and imperfective aspects by adding suffixes to the verbs, as in zòe 'have run' and zòró 'running'.

Most Mabia languages exhibit the Subject Verb Object order in their basic sentence patterns. Another prominent syntactic typological characteristic includes verb serialization, a syntactic construction in which two or more lexical verbs may share arguments without intervening connectors. The issue of verb serialization or serial verb constructions has been the topic of much discussion in theoretical linguistics and, in this respect, Dagaare and other Mabia languages have contributed very interesting research data.

\section{TEXTS AND LINGUISTIC TRANSCRIPTIONS}

As far as possible, the various texts associated with the music on this recording are presented with tonal transcriptions. For phrases and larger chunks of data, we provide interlinear glossings. These glossings provide interesting insights into the grammatical and communicative structure of the Dagaare language. Finally, free translations follow the glosses to capture salient aspects of the linguistic and cultural meaning behind these texts. This linguistic data transcription is an important aspect for the analysis and interpretation of the music texts. The following is an illustration:

$\begin{array}{llllllll}\text { kà néc biéng } & \text { wá } & \text { b̀̀ng } & \text { báwáá } & \text { tènéé } & \text { páálòng } & \text { bîé } & \text { náá } \\ \text { COMP person } & \text { child.FOC NEG } & \text { know } & \text { báwáá } & 1 . P L & \text { area } & \text { child } & \text { NEG }\end{array}$

'If a child doesn't know how to dance báwáa' s/he cannot possibly be a child from our town.'

In this sung text, the first line is the Dagaare enunciation, with the high and low tone markings on all the words and particles in the sentence. In the second line, is a gloss of the grammatical category or the literal meaning of the word. The grammatical category COMP indicates that the first word begins with a complementizer 'if'. This is followed by the word 'person', then 'child'. As can be seen, a grammatical element FOC standing for 'focus marker' is attached to this lexical item 'child'. All this is followed by the grammatical item NEG standing for a particle or element that marks negation. This is followed by the verb 'know' then by 'ba'wa'a', which means a special kind of dance, so we leave the latter word as it stands. This is followed by a grammatical item 1.PL which stands for 'first person plural marker'. Finally, we have the items 'area', 'child', and another negation marker completing the glossing of this Dagaare sentence/enunciation. The third line provides a free translation of the whole enunciation. This is not meant to be an exact translation but rather an attempt to capture the essence of the meaning and cultural significance of what is being conveyed. Other abbreviations of grammatical 
categories are: PART = particle; 1, 2, $3=$ First, second and third persons; $\mathrm{SG}=$ singular; PAST = past tense; FUT = future tense; $\mathrm{PERF}=$ perfective aspect; IMP = imperfective aspect; $\mathrm{NOM}=$ nominalization; $\mathrm{NEG}=$ negation; $\mathrm{DEF}=$ definite article; $\mathrm{CONJ}=$ conjunction; $\mathrm{DIR}=$ directional verb; $\mathrm{ORD}=$ ordinal number LOC $=$ locative $; \mathrm{TOC}=$ topic $; \mathrm{DEM}=$ demonstrative.

\section{DAGAARE MUSIC}

While the music obtained from this fieldwork is the expression of a distinct ethnolinguistic group, the Dagaaba, nevertheless, have had long historical, social, cultural and linguistic ties with other peoples of the northern parts of Ghana, such as, the Sisaala, the Waala, the Dagomba, the Frafra, the Kasena, the Builsa, the Kusaasi and the Mamprusi. Thus, the musical cultures of the region share certain features (Vetter 2000). For instance, the main instrument of the northwestern part of the country is the xylophone (see Figure 2), which may be supported by a drum or a drum ensemble, and the scales are largely of the hemitonic and anhemitonic pentatonic types.

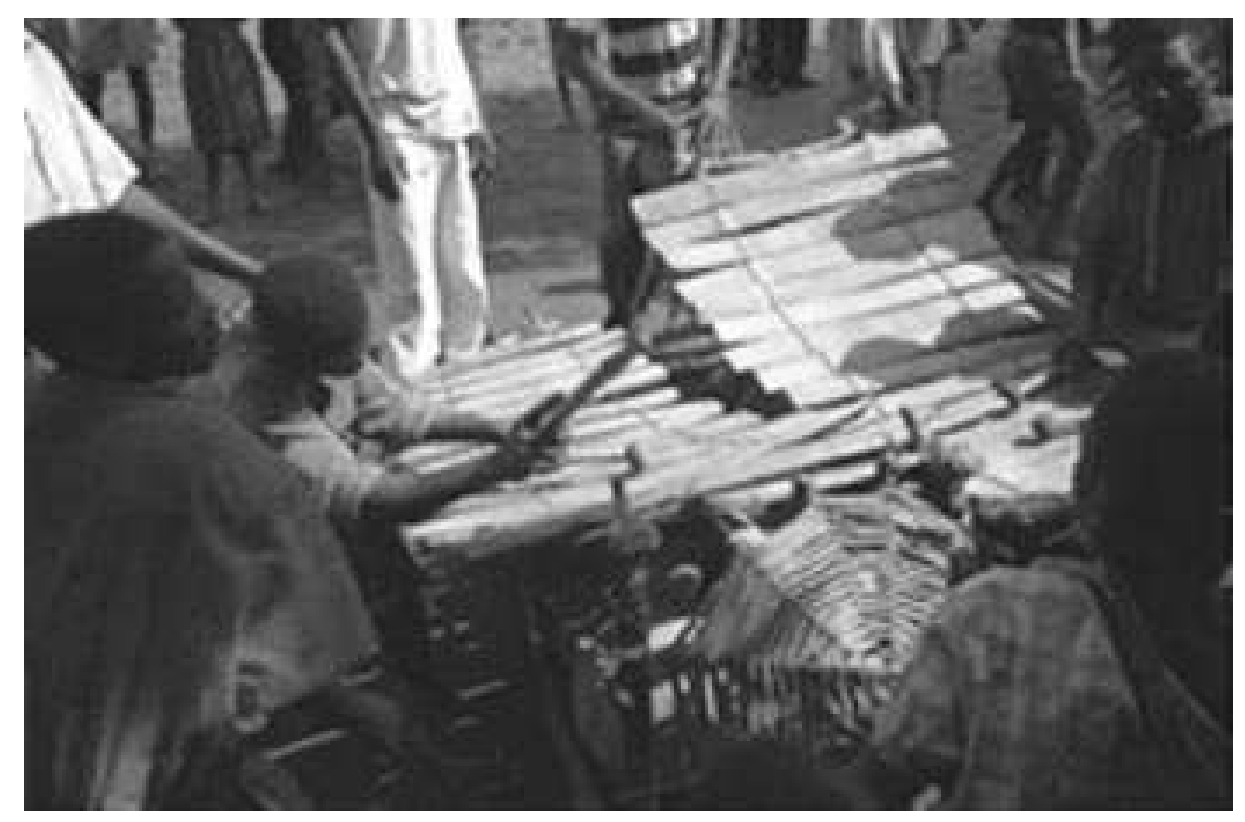

Fig. 2. Xylophones indigenous to northern areas of Ghana.

Music-making among the Dagaaba, like other peoples of the region, is an intrinsic part of social life. Certain types of music and repertories of song may be associated with particular occasions, cults, cooperative work groups and organized labour, age groups, and rites of passage. For instance, praise-songs (dànnóng) are performed regularly as a tribute to the chief while other types of music are exclusive to the rituals and ceremonies of the royal court, such as, an investiture, an assembly in the court or audience chamber, or a funeral. Particular types of music are identified with the religious cult called bàgré which holds an annual festival; or with traditional associations, such as the kpètáa, which comprises reciprocal help groups for young farmers. The ánlée social dance is reserved for females; the féròo is a dance performed by the youth; while the se żgàanáa is danced mainly by the elderly. There are warrior songs (ż̀̀̀ré yiélè), as well as songs for farming, grinding, pounding, floor-beating, plastering, hunting (wààròng y̌̈elè) and herding. There are special songs for initiation ceremonies, funerals (kòbié), ritual sacrifice, weddings, and public naming ceremonies that occur seven days after the birth of a child (referred to as 'outdooring'). On some occasions, certain types of music may be prohibited, for instance, the báwáa is not performed when a member of the community is seriously ill or when someone has died. Music may also occur as the spontaneous expression of individual community members, such as the music for the solo bamboo flute (wüléé), the harp ( $p \grave{c} n \hat{a} a$ or koriduo in Nandom), or the lullaby (bì-yáglèyiélè). Finally, music is used to welcome and honour important guests and visitors, as illustrated during our visit to Kogri, the ancestral home of Adams Bodomo: 
We arrived in Kogri at around 1:30pm. All the members of the village, as well as those from neighbouring villages, had gathered to greet us. They had been waiting for our arrival since morning. The chiefs and elders sat ceremoniously in a row under the massive Baobab tree while the women and girls danced the ánlée. As we got out of the jeep, the dance and music intensified. The dancers moved in a circle under the trees to the accompaniment of a drum played by an adult male. Some young boys hammered on the xylophones some distance away from the dancers. The women danced, clapped and sang heartily as black rain-clouds gathered threateningly overhead. I prepared the recording equipment and began to record when suddenly the rain poured, the thunder rumbled and lightening flashed across the sky. We had just enough time to get the recording equipment out of the rain, but the dancers kept on. I attempted to continue with the recording while under an umbrella but in vain. How frustrating it was to witness the exhilarating welcome, which lasted uninterrupted until dusk. All we could do was hope for better weather in the morning as most of the folks present promised they would return. [from Mora's field notes]

Listening examples include: báwáá dance music, xylophone duets, individually sung folktales (sénselllè) and spoken folktales, women's dance songs (ánléé), and women's praise songs (dànnóng). Performances of báwáa and xylophone duets recorded in the social clubs of Dagaaba immigrants in Accra can also be heard. The báwáa and xylophone selections give some idea of the kind of social music that still thrives within Dagaare communities in both rural and urban settings and they make up the bulk of the recordings we made. Indeed, the báwáa is one of the most important cultural practices of the Dagaaba so aspects of its performance and structure are described in some detail.

\section{THE Báwáá DANCE}

Group dancing is intrinsic to ceremony; it is a marker of social competence and a way of maintaining community solidarity. The báwáa is a call to young people to dance and make music together, indeed the term báwáa literally means, 'young people, come together'. Normally, the báwáa is incorporated into rites of passage marking birth, puberty, marriage and death, though it may also occur spontaneously.

The báwáa dancers, which may comprise both young males and females also make up the chorus (see Figure 3). One of the dancers, normally a male with the most skill or experience as a dancer or instrumentalist, takes the role of lead singer (báwà-ngmáára') or 'the cutter' (báwà-kyéźr $\hat{\text { ) }}$. The dancers are accompanied by two xylophonists, one plays a 'male' instrument (gyil-dáa) and the other plays a 'female' instrument (gyil-nyáníngáa), and a drummer who normally plays a double-headed, stick drum (gànggàa'). The terms 'male' and 'female' xylophones are more of specialist terms among

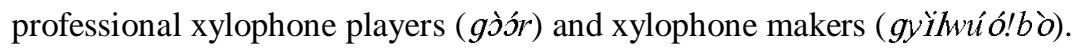




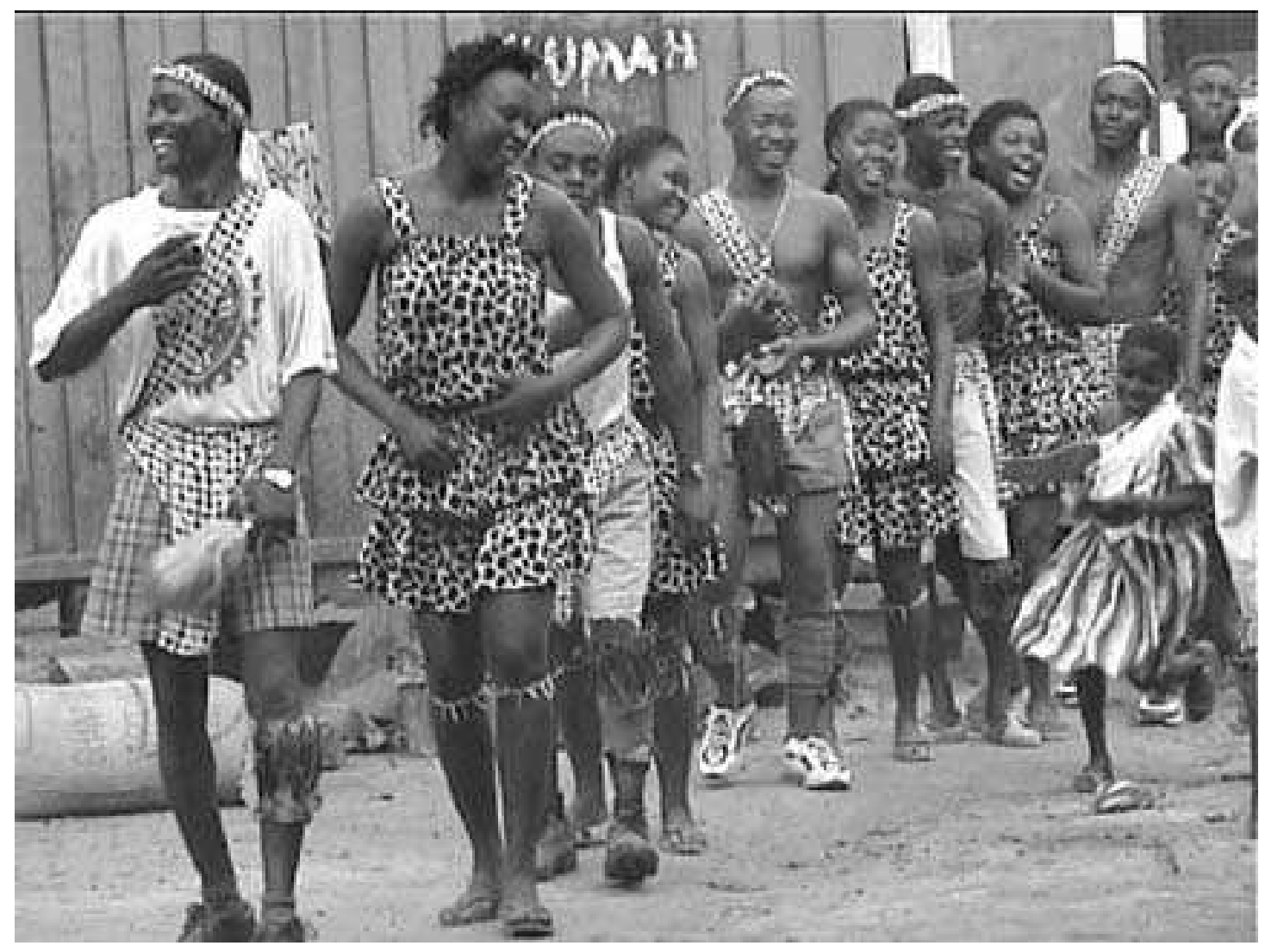

Fig. 3. Báwáa dancers.

The leader of the dance-chorus decides when one song ends and when a new one begins, though the xylophonist may also decide when the change should occur. This practice may involve some power play, in terms of who is more influential. The chorus, called bàwà-ságérebá (or ságrá: singular 'one who agrees'), responds to the calls from the leader. The dancers wear metal leg jingles (kyéém $\hat{\varepsilon})$ illustrated in Figure 4, beaded girdles (lèbiè), metal finger cymbals (péràà pl. pérrè) and sometimes metal wrist jingles. 


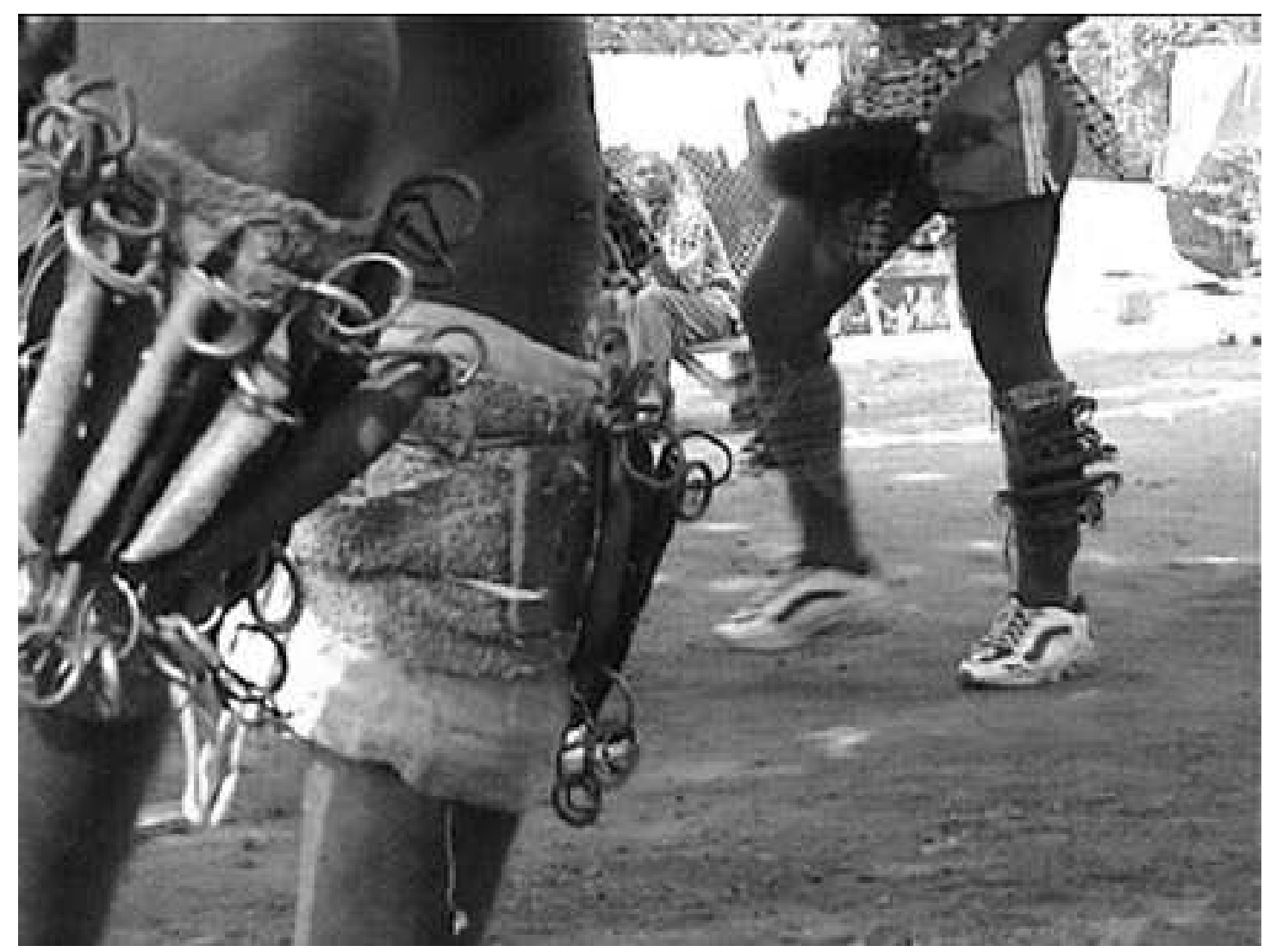

Fig. 4. Metal leg jingles worn by dancers (Accra).

The call to dance normally begins with the sounding of finger cymbals. The two xylophone players, who sit facing each other, begin while the crowd gathers around the dance area. The dancers then enter the area and form a circle around the musicians, dancing in an anti-clockwise or clockwise direction. The dance event is normally directed by the báwáa nàa who does not participate in the dance itself.

The main part of the dance consists of an alternation between two sections: the sé ćó, which features call and response singing, and the tòòléré or émmó ('to put in'), which features intense dancing using heavy, syncopated accents and displays of skill. This cycle is repeated any number of times for each song, until the leader signals a new song and the cycle begins again. Generally, a performance lasts between twenty and thirty minutes.

\section{The Xylophone and Drum}

Dagaare xylophones are tuned to an anhemitonic pentatonic scale and have a range of two octaves (Saighoe 1984). The instruments are tuned to the same scale though the 'female', lead instrument (gyilnyángáá), is said to have a higher or sharper 'voice' (à kjkórì) than the 'male', (accompanying instrument (gyildáa), which has a lower voice. Sometimes the 'male' xylophone can lead, especially in playing fast song dances like the férò, while it is more natural for the 'female' to lead in slower song dances like the sìggàànáà. Gourd resonators $(k o \hat{z})$, graduated in size, are suspended under each xylophone key. Two or three holes about $2-3 \mathrm{~cm}$ in diameter are bored into each gourd and each is covered with a spider's egg case (pàà $\hat{I})$ to increase the resonance and to produce a buzzing effect.

The cylindrical double-headed drum (gàngàa ), which is fitted with cow or antelope skin and played with two sticks, normally accompanies the xylophones in the báwáa dance, as was the case in Kogri, though sometimes two single-headed drums, one big (gàngàkpóng) and the other small (gàngà léé) are used. The gourd drum (kórè), which is fitted with iguana skin and played with the hands, is normally reserved for funerals; in the Accra, though, it was used to accompany báwáá. 


\section{BRIEF COMMENTS AND EXPLANATIONS OF THE CULTURAL SIGNIFICANCE OF THE SPOKEN AND SUNG TEXTS (LISTENING EXAMPLES 1-35)}

We now briefly comment on and explain the cultural significance of these recordings which were made in August 2000 in Kogri and Accra. They include báwáa dance, xylophone duets, sung folktales (sénsell ż-yiéle), spoken folktales (sénsellè), and women's dance songs (ánléé) and praise songs (dànnóng). The báwáa and xylophone selections are indicative of the social music that thrives within Dagaare communities in both rural and urban settings and make up the bulk of our selections.

Tonal transcriptions of the song texts are provided, with the high and low tone markings over the vowels and nasal consonants of words and particles. In the Dagaare orthography there are altogether 31 graphemes, including vowels such as the open $\mathrm{e}, \varepsilon$ and the open $\mathrm{o}, \boldsymbol{\supset}$. The free translations in English that follow the transcriptions are intended to convey the meaning and cultural significance of the text. We have divided these recordings into 'Listening Examples' closely following the order in which they appear in the CD documentation that has been submitted to UNESCO (Mora and Bodomo forthcoming).

Listening Examples 1-4: Báwáá (Performed by the people of Kogri)

Download sound files for Listening Examples 1-4 using these links: https://kb.osu.edu/dspace/bitstream/1811/28815/1/EMR000028a-01-dagaaba.ogg) https://kb.osu.edu/dspace/bitstream/1811/28815/2/EMR000028a-02-dagaaba.ogg) https://kb.osu.edu/dspace/bitstream/1811/28815/3/EMR000028a-03-dagaaba.ogg) https://kb.osu.edu/dspace/bitstream/1811/28815/4/EMR000028a-04-dagaaba.ogg)

This performance of báwáá contains four renowned songs. The first is Bá yáá wáé lá, a 'signature song' used by a báwáa dance group in competitive events. In the recording, the Kogri villagers throw

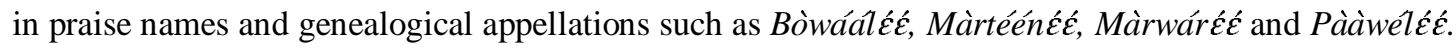
The second song, Ándón $\varepsilon \dot{\varepsilon}$ y $\dot{\varepsilon}$ nòoró, exhorts people to be wary in an uncertain world. The third song, Kónóó wààná yéé, is a consolatory message to those who have tenuous links with the community.

L.E. 1. Bá yáá waé lá yéé - They have come again

Bá yáá wáé lá yéé

3.PL again come FOC PART

'They have come again'

Bá yáá wáé lá yéé

3.PL again come FOC PART

'They have come again'

Bòwááléć y!áá wáé lá yéé

Bowaalee again come FOC PART

'Bowaalee have come again'

A yàà wà né pólóó

DEF again come with pride

'Coming again with pride'

Bá yáá wáé lá yéé

3.PL again come FOC PART

'They have come again'

Bá yáá wáé lá yéé

3.PL again come FOC PART

'They have come again'

Bòwááléć y!áá wáé lá yéé

Bowaalee again come FOC PART

'Bowaalee have come again' 
A yàà wà né pólóó

DEF again come with pride

'Coming again with pride'

Pààwéléć y!áá wáé lá yéé

Pààwélé á again come FOC PART

'Paawelee have come again'

Màrteénéć y!áá wáé lá yéé

Màrtééné $\varepsilon$ again come FOC PART

'Mareteenee have come again'

Màrwáréć y!áá wáé lá yéé

Màrwáréć again come FOC PART

'Marwaree have come again'
A yàà wà né pólóó
DEF again come with pride
'Coming again with pride'

L.E. 2. Ándónéé yé nòòró - People of the world tread carefully

Andónéé yé nòòró yéé (repeat many times)

Masses 2.PL move back PART

'People of the world be careful.'

Kúú bé pùớí yàà tè wááná (repeat many times)

Death be back again DIR come

'Death is imminent.'

Bòwááléć yé nòòró yéé

Bowaalee 2.PL move back PART

'Bowaalee be careful.'

Kúú bé pùorí yàà tè wááná

Death be back again DIR come

'Death is imminent.'

L.E. 3. Kònó wààná yéé - Oh, come mourn with us

Kònóó wááná yé

Weep-IMP come-IMP PART

'Come along and mourn!'

Kónóó wááná yéé

Weep-IMP come-IMP PART

Come along and mourn!

Fò náng wá táá sáá né má

2.SG yet NEG have father and mother

'Though parents you no longer have' 
Kyó méng kònóó wááná lé

but.2.SG also weep come PART

'You may also still come along to mourn with the others.'

Kyó méng kònòò wáánà lé

but.2.SG also weep come PART

'You may also still come along to mourn with the others.'

Kónóó wááná yéé

Weep-IMP come-IMP PART

'Come along and mourn!'

Kónóó wááná yéé

Weep-IMP come-IMP PART

'Come along and mourn!'

Bèkpéé wá táá sáá né má orphan NEG have father and mother

'Though, orphan as you are - no longer having parents'

Kyá méng kònòò wáánà lè

but.2.SG also weep come PART.

'You may also still come along to mourn with the others.'

Hiiné wááná yéé

Wail-IMP come-IMP PART

'Come along and wail!'

Hiíné wááná yéé

Wail-IMP come-IMP PART

'Come along and wail!'

Fó náng wá táá sáá né má

2.SG yet NEG have father and mother

'Though parents you no longer have'

Kyó méng híiné wááná lé

but.2.SG also weep come PART

'You may also still come along to mourn with the others.'

Kyá méng hîiné wáánà lè

but.2.SG also weep come PART.

'You may also still come along to mourn with the others.'

L.E. 4. Néébó- Whatever you do...

$\mathrm{N}$ éébó yáá (repeat many times)

1.SG do.NOM PART

'My deeds.'

N páá móó éć néé yélỉ kàng

1.SG now always.come do somebody thing some

'Sometimes when I relate to some kinds of people'

Wà là bòng $\mathrm{N}$ éébó yáá

NEG FOC know 1.SG do.NOM PART

'I don't really know how best to thread.' 
Kà $\quad \mathrm{N}$ bààrá lá béé

COMP 1.SG grow.IMP FOC PART

'Whether I will survive this'

Kà N kpìré lá béé

COMP 1.SG die.IMP FOC PART

'Or I will perish from this,'

N páá móó é lá néé yéli kàng

1.SG now always.come do FOC somebody thing some

'Sometimes when I relate to some kinds of people'

Wà là bòng $\mathrm{N}$ éébó yáá

NEG FOC know 1.SG do.NOM PART

'I don't really know how best to tread.'

Listening Examples 5-7: Gy̆lé ngmééó (né lénnòò) - Xylophone Duets

Download sound files for Listening Examples 5-7 using these links:

https://kb.osu.edu/dspace/bitstream/1811/28815/5/EMR000028a-05-dagaaba.ogg)

https://kb.osu.edu/dspace/bitstream/1811/28815/6/EMR000028a-06-dagaaba.ogg)

https://kb.osu.edu/dspace/bitstream/1811/28815/7/EMR000028a-07-dagaaba.ogg)

This is performed by Dekongmen Bodomo (lead player) and Bayuo Digre (support player) from Kogri. While xylophone performance is essential to funerary rites, it also serves a recreational purpose. Such performances normally consist of a medley of compositions intended to illustrate the skill and inventiveness of the lead player, who plays the main melody and variations, and the supporting player, who provides accompanying melodic patterns and rhythmic ostinati (time-line patterns). In these recordings, the time-line patterns fit into regular grouping of beats or irregular groupings that cut across the phrase structure of the composition. An example of the former type of time-line pattern may be

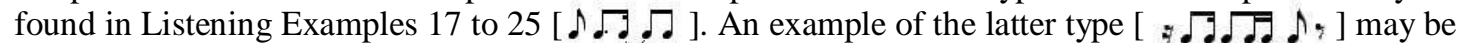
found in Listening Example 6. In this last example, the time-line extends over three beats and is repeated four times within the twelve beat composition.

L.E. 5. Kúú yóng téng téng... Only death is supreme. You may do anything but you can't subdue death.

Kúú yóng téng téng

'Only death!'

Kúú náng wáá gàndáá

'It is only death that is the ultimate hero.'

Kúú yóng ká bá máng wá só

'It is only death that can't be controlled.'

L.E. 6. Ngmàángà dà kóng zóró báá...If you have support in this world, you can really achieve progress

Ngmàángà dà kóng zóró báá

'Why wouldn't Monkey fear dog?'

Báá náng táá pòtééré

'Dog has a supporter.'

Ngmàángà méng pòtééré bé?

'But where is Monkey's supporter?'

L.E. 7. Kúú yéng yéng lé... You may do all kinds of heroic things but one day you will have to come up to death 
Kúú yéng yéng lé

'Death is so near.'

Kyéng kyé gàànè

'Walking in a stride'

Kyéng kyé gàànè

'Walking in a stride'

Kúú yéng yéng lé

'Death is so near.'

\section{Listening Example 8: Sénséllè yiélúníg (Sung folk tales) - Downtrodden of the world} (Performed by Bayиo Digre of Kogri)

Download sound file for Listening Example 8 using this link:

https://kb.osu.edu/dspace/bitstream/1811/28815/8/EMR000028a-08-dagaaba.ogg)

In this song, the singer draws attention to the plight of the weak, the disabled and the disadvantaged in society.

Tóò màà Báyúó Dìgré, màà lá bóórò ká éng yiélí à yiélúng

Ok, 1.SG bayuo Digre, 1.SG that want-IMP COMP I sing DEF song

'OK, it is me Bayuo Digre that wants to sing the song.'

Nààngménè zú nénsááná

God head person-spoil

'Disabled of the world'

Nààngménè zú nénsááná

God head person-spoil

'Disabled of the world'

Yé máng nyé

2.PL always see

'Oh please consider (them).'

Zòngó mèng yòng máng náá

Blind also alone always NEG

'The blind should not be left to their fate alone'

Kòngó mèng yóng máng náá

Leper also alone always NEG

'Lepers should not be left to their fate alone'

Tè zàà yélé

1.PL all matter

'This is an issue for all of us.'

Sèc̀ táá yî̀ kóróng

Better than other exist long ago

'Differences in abilities have always existed.'

Kà nééng wá dàng séćbó

COMP person come first better than

'If a fellow has a higher ability' 
Tá nyé súúrí

NEG see anger

'Don't get frustrated.'

Kà nààngménéng dà wàà péć

COMP God.TOP PAST become roof.top

'If God were only a roof-top away,'

Kàng dó bé ká té nyé táá

COMP.1.SG climb there CONJ. 1.PL see each other

'I would have climbed up there to consult with him.'

Kyع́ kàng sòòròò yélé

CONJ COMP. 1.SG ask matter

'And I would have asked him a few questions.'

$\mathrm{N}$ dòmó káǹg tá mààlè

1.SG totem COMP.1.SG NEG develop

'My totem wouldn't allow me to improve my situation.'

$\mathrm{N}$ dòmó káǹg tá mààlè

1.SG totem COMP.1.SG NEG develop

'My totem wouldn't allow me to improve my situation.'

N má bíírí wóó

1.SG mother children PART

'Oh, my brethren!'

Listening Example 9: Sénséllè yiélúng (Sung folk tales) - Living cautiously

(Performed by Bayuo Digre of Kogri)

Download sound file for Listening Example 9 using this link:

https://kb.osu.edu/dspace/bitstream/1811/28815/9/EMR000028a-09-dagaaba.ogg)

The belief in witchcraft and the supernatural encourages caution amongst the Dagaaba. However, the supreme deity, Nààngmén, is the ultimate arbiter of human affairs and, in the end, mortal enemies do not have the power to carry out their evil wishes!

Ká N tá yóbró wéllè

COMP 1.SG NEG roam-IMP wildly

'My enemy would not want me to walk around freely.'

Déndómó é lá á Náángménè béé

Enemy be FOC DEF God PART

'Is my enemy God?'

Déndómó yèli ká $\mathrm{N}$ tá yóóró wèllè

Enemy say COMP 1.SG NEG roam-IMP wildly

'My enemy wishes I could not walk around so freely.'

Déndómó é lá á Náángménè béé

Enemy be FOC DEF God PART

'Is my enemy God?'

Fò móó é lá á Náńngménè béé

2.SG anyway be FOC DEF God PART

'Are you God anyway?' 
Fò mó é lá á tèngán béé

2.SG anyway be FOC DEF God of the earth PART

'Are you God of the Earth anyway?'

Déndómó yèl káng tá yóóró wéllè

Enemy say COMP.1.SG NEG roam.IMP wildly

'My enemy wishes I could not walk around so freely.'

Déndómó è lá á tèngán béé

Enemy be FOC DEF God of the earth PART

'Is my enemy the God of the Earth anyway?'

Gbònggbòri yéli kò wá bóóró bóó

Hyena say COMP.3.SG NEG want.IMP goat

'Hyena says he doesn't like Goat.'

Wénáá yèli kò wá bòórò bó

King-of-the-wild say COMP.3.SG NEG want.IMP goat

'Lion says he doesn't like Goat.'

Yéǹg kó ngmàà bàrè ká bó yóóró

Where COMP.2SG cut leave COMP goat roam.IMP

'Where have you set aside for Goat to roam?'

\section{Listening Example 10: Sénséllé Séllòò (Spoken tales) - The origin of diseases (Performed by Bayuo Digre of Kogri)}

Download sound file for Listening Example 10 using this link: https://kb.osu.edu/dspace/bitstream/1811/28815/10/EMR000028a-10-dagaaba.ogg)

This folktale is a mythological explanation for the prevalence of disease in society and is a favorite among the Dagaaba. Bádéré, an inquisitive spider and trickster, is at the centre of an unfortunate discovery. He wanders deep into the wilderness and arrives at a sealed aerie in which all diseases are contained. When he hears strange sounds emanating from within, his curiosity gets the better of him and he opens it unleashing all the diseases upon the world. An additional moral here is to refrain from unbridled curiosity.

Listening Example 11: Sénséllé Séllòò (Spoken tales) - No one woman can give birth to a hero (Performed by Bayuo Digre of Kogri)

Download sound file for Listening Example 11 using this link:

https://kb.osu.edu/dspace/bitstream/1811/28815/11/EMR000028a-11-dagaaba.ogg)

This is a typical West African story of "man pass man". As we increase our horizons, we may take stock of our weaknesses and strengths. Each of the Herculean men in this folktale meets an even more gigantic and powerful creature as each wanders into unfamiliar territory. Their discoveries are aptly expressed by a Dagaare moral: No one woman can give birth to a hero!

Sound Examples 12-14: Ánléé (women's dance songs) (Performed by the women of Kogri)

Download sound files for Listening Examples 12-14 using these links: https://kb.osu.edu/dspace/bitstream/1811/28815/12/EMR000028a-12-dagaaba.ogg) https://kb.osu.edu/dspace/bitstream/1811/28815/13/EMR000028a-13-dagaaba.ogg) https://kb.osu.edu/dspace/bitstream/1811/28815/14/EMR000028a-14-dagaaba.ogg)

The performers of these dance songs (see Figure 5) complain about the predicament of women in Dagaare society. They disclose, spontaneously, their feelings of helplessness and frustration, but also their resilience and resolve to do better. 


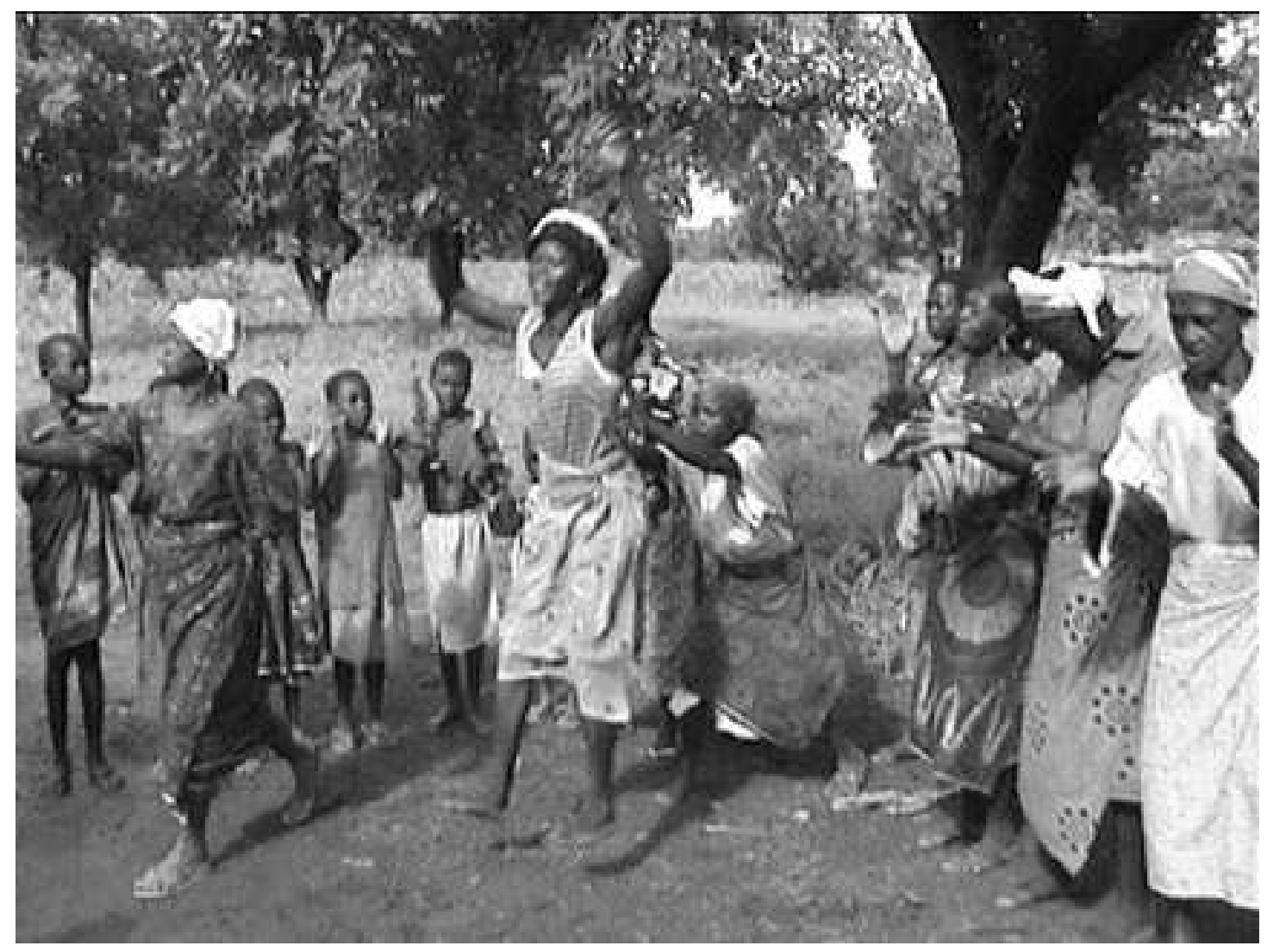

Fig. 5. Ánléé women's dance.

L.E. 12. Némbààlá òhóó...

Person-poor PART

'Oh poor helpless person...'

(Kó mó yó yèlibílé

COMP.2.SG always.come say thing.small

'You may say something trivial,'

Kyé wà wònáà kà áná náá)

But come hear.3.PL COMP 3.PL NEG

'But it gets exaggerated when next you listen to people talk of it.'

L.E. 13. $N$ wá là bòng $N$ bò̀ré nyé (repeat 2 or more times)

1.SG NEG again know 1.SG sacrifice DEM

'I really cannot decipher this one fate of mine.'

N bóóré wóóré nyé yàà

1.SG god problems these PART

'These divine problems of mine'

N wá lá bóngéng bóbrè nyé

1.SG NEG again know.1.SG God this

'I don't know what to do with them.' 
L.E. 14. Táá yélé yéé táá yélé. (repeat many times)

have matter PART have matter

'Sacrifices and problems,'

Bòòré mèng yòng nàá táá yélé (repeat many times)

God also alone NEG have matter

'It is not only gods that one must make sacrifices to.'

Bààlá mèng yòng nàá táá yélé (repeat many times)

Sick also alone NEG have matter

'It is not only the weak that has problems.'

Listening Example 15: Yé èngné yè Nàá - Respect your King (Performed by the women of Ullo and led by Marcelina Bongnea)

Download sound file for Listening Example 15 using this link:

https://kb.osu.edu/dspace/bitstream/1811/28815/15/EMR000028a-15-dagaaba.ogg)

In this song, the women of Ullo sing the praises of their chief and exalt his lineage. The lead singer urges her community to respect and honor the chief, and to strengthen her message she alludes to how citizens of a neighboring community venerate their chief.

Yé èngné yè Nàá (repeat many times)

2.PL respect.IMP 2.PL Chief

'Respect your Chief!'

Yદ́ èngné yè Nàá

2.PL respect.IMP 2.PL Chief

'Respect your Chief!'

Kà nóbذ̀ nyé sòng èng kò yé

COMP people see help respect give 2.PL

'So that people may realize how worthy he is.'

Kówááré nàng táá Bà-wá-bóórò-nóbò

Koware clan as have Bawaboorsnobs

'Don't you see how the Kowaare clan'

Bà máng wá èng gàngàà lè

3.PL always come respect surpass that

'respect Chief Bawabooronoba so much.'

Dàntećléć yé èngné yè Nàá

Dante $\varepsilon$ people 2.PL respect.IMP 2.PL Chief

'People of Danteع, respect your Chief!'

Sòzééléć yé èngné yè Nàá

Sòzééléć 2.PL respect.IMP 2.PL Chief

'Sòzéélé ع', respect your Chief!'

Listening Example 16: Exaltations to the Youth (Performed by the women of Ullo and led by Marcelina Bongnea)

Download sound file for Listening Example 16 using this link: 
In this song, the singer urges the people of Ullo to join together in the interest of advancing their community. She invokes the founder of their clan and recites various lineage appellations to intensify her exhortation.

$$
\begin{aligned}
& \text { Bà yó sààná yé lá } \\
& \text { 3.PL go.around spoil 2.PL PART } \\
& \text { 'They are going around castigating you' }
\end{aligned}
$$

Ká yè kòng tój̀ è yélỉ

COMP. 2.PL NEG able do thing

'That you can't do anything.'

Yé dé yè tééróng lángnè Nààngménè

2.PL take 2.PL thoughts put God

'Put your faith in God.'

Bàyóǹg bỉirỉ yé nà tój̀ lèè sáámá kà bá yí

Bayong children 2.PL FUT able help strangers and they going

'Children of Bayong, can you entertain guests?'

Yé dé yè téćróńg lángnè Báyóng

2.PL take 2.PL thoughts put Bayong

'Put your faith in Bayong.'

Yé dé yè téćróńg lángnè Nààngménè

2.PL take 2.PL thoughts put God

'Put your faith in God.'

Yé nà tóò è lá

2.PL can able do PART

'You can do it.'

Dàntećléć bỉirí bà yó sààná yé lá

Children of Danteع 3.PL go.around spoil 2.PL PART

'Children of Danteع, people are going around castigating you.'

Tî̀ròńgdèmé, yé dé yè téćróńg làngné Nààngménè....

Tiirongdeme 2.PL take 2.PL thought put God

'Tiirongdeme, put your faith in God.'

Listening Examples 17-25: Xylophone duets (Performed by Pius Nanfuri and Bakyogyi Bonkangsaa from the Langzel Báwáá Troupe in Accra)

Download sound files for Listening Examples 17-25 using these links:

https://kb.osu.edu/dspace/bitstream/1811/28815/17/EMR000028a-17-dagaaba.ogg) https://kb.osu.edu/dspace/bitstream/1811/28815/18/EMR000028a-18-dagaaba.ogg) https://kb.osu.edu/dspace/bitstream/1811/28815/19/EMR000028a-19-dagaaba.ogg) https://kb.osu.edu/dspace/bitstream/1811/28815/20/EMR000028a-20-dagaaba.ogg) https://kb.osu.edu/dspace/bitstream/1811/28815/21/EMR000028a-21-dagaaba.ogg) https://kb.osu.edu/dspace/bitstream/1811/28815/22/EMR000028a-22-dagaaba.ogg) https://kb.osu.edu/dspace/bitstream/1811/28815/23/EMR000028a-23-dagaaba.ogg) https://kb.osu.edu/dspace/bitstream/1811/28815/24/EMR000028a-24-dagaaba.ogg) https://kb.osu.edu/dspace/bitstream/1811/28815/25/EMR000028a-25-dagaaba.ogg) 
Like the Kogri xylophone performance (Listening Examples 5-7), the Accra players perform a number of compositions in medley fashion. The Accra performance, however, is characterized by a denser rhythmic and melodic texture, a faster tempo, and the insertion of sung phrases.

L.E. 17. Kòrì wà yírì yéé (repeat) grow.old come house PART

'Grow-old-come home,'

L.E. 18. Zòrò néngfáá (repeat)

fear-IMP person-bad

'Beware of a bad person.'

L.E. 19. pó5 yélỉ yéé, ̀̀ póó yélỉ, nèé kòng bóng, (repeat) stomach matter PART, 1.SG stomach matter person NEG know

'No one can know too much about a person's inner feelings'

Kàng gbïréé yéé, kàng bà gbíri yéé, nèé kòng bóng COMP.1.SG sleep PART COMP.1.SG NEG sleep PART, person NEG know 'Whether I sleep or not, no one can know exactly.'

L.E. 20. N má wóó pirì má kyéémé káng yỉ yèngé séé báwáá (repeat) 1.SG mother PART wear 1.SG jingles COMP.1SG go out dance báwáá 'Mother, please put some jingles on me to go out and dance báwáá.'

L.E. 21. Tèmpèlòńg né ngmáné, ànná záá kà máriá kyỉiré (repeat) ash and calabash all these COMP Christian dislike.IMP 'A calabash full of ashes and all such things are what Christians dislike.'

L.E. 22. Bóng kàngá lá mélé góngólóng à nyè wà sògláà zòòré (repeat) thing some that coil around and like snake black tail 'There is something coiled around like the tail of a black snake.'

L.E. 23. $\mathrm{N}$ bá kàngkàngnúúléé nàng póré kàngkàngàá ló má (repeat) 1.SG friend kangkangaa.bird please pluck kangkangaa.fruit throw 1.SG 'My friend the kangkangaa bird, please get me a kangkangaa fruit.'

L.E. 24. Sááláá béróng (yàà) (repeat many times) food.bowl fat PART 'A fat bowl of saabo,'

A máng diré bá tégré

DEF always eat.IMP NEG satisfied

'One keeps eating and never gets full.'

L.E. 25. Kúú sórí lá yèng...(repeat many times)

Death road FOC where

'Where is the way to Death?'

Listening Examples 26-35: Báwáá (Performed by the Langzel Báwáá Troupe from Accra)

Download sound files for Listening Examples 26-35 using these links: https://kb.osu.edu/dspace/bitstream/1811/28815/26/EMR000028a-26-dagaaba.ogg) https://kb.osu.edu/dspace/bitstream/1811/28815/27/EMR000028a-27-dagaaba.ogg) https://kb.osu.edu/dspace/bitstream/1811/28815/28/EMR000028a-28-dagaaba.ogg) https://kb.osu.edu/dspace/bitstream/1811/28815/29/EMR000028a-29-dagaaba.ogg) https://kb.osu.edu/dspace/bitstream/1811/28815/30/EMR000028a-30-dagaaba.ogg) https://kb.osu.edu/dspace/bitstream/1811/28815/31/EMR000028a-31-dagaaba.ogg) https://kb.osu.edu/dspace/bitstream/1811/28815/32/EMR000028a-32-dagaaba.ogg) https://kb.osu.edu/dspace/bitstream/1811/28815/33/EMR000028a-33-dagaaba.ogg) 
https://kb.osu.edu/dspace/bitstream/1811/28815/34/EMR000028a-34-dagaaba.ogg)

https://kb.osu.edu/dspace/bitstream/1811/28815/35/EMR000028a-35-dagaaba.ogg)

This báwáa performance also consists of a medley of songs that illustrate salient themes: bravery, morality, community solidarity, and seasonal migration to urban centres. The performance is noticeably more intense than the Kogri performance mainly due to the prevalence of marked syncopations in the gourd drum (kóórè).

L.E. 26. Annónéć wá táá yél.. (repeat many times) masses NEG have [something] 'Humanity does not have [inaudible..]'

L.E. 27. Kómmíé wóó, (repeat several times) tomato.PL PART 'Oh, tomatoes!'

Dàngmà sògláà nàńg wóng kómmíé Wood.short black just bear tomato.PL 'A black piece of wood bearing tomatoes!'

L.E. 28. Pòòléé náng vèćlé lé kyé nyóg kpááléé èng séngéng (repeat) woman.small as beautiful that but catch guinea.fowl-small put jar.inside 'Oh, what a beautiful girl but she has tried to hide a small guinea fowl in a jar!'

L.E. 29. Wà yí ká tè gàà màné (repeat many times) come go.out COMP 1.PL go sea

'Come, let's go to the Coast.'

L.E. 30. Lágélágé yélméngé léé pî́ ká bá máng zélé (repeat many times) Bitter bitter truth turn arrow COMP 1.PL always poison 'Like an arrow, truth can get poisoned.'

L.E. 31. Ká nógráá ìrí kúlò kyéká bá máálè bà téngé (repeat many times) COMP alien get.up go.home.IMP and 1.PL make 1.PL land 'They say that aliens should go back home and let them develop their country.'

L.E. 32. Kóóséé nómé ná (repeat many times) cakes sweet.PERF FOC 'Cakes are sweet.'

Kyáá dààróng wàà túó But.3.PL cost be bitter 'But they are costly.'

L.E. 33. Bïpól’̀ máng nòng lá táá (repeat many times) child.young always like FOC other 'The youth ought to like each other.'

Bìpólò wá kyỉiré táá

Child.young NEG hate other

'The youth should not hate each other.'

L.E. 34. wáá wáá wáá wáá (repeat many times) PART PART PART PART 'Oh, Oh, Oh, Oh...'

L.E. 35. Kúú wóó, kúú wóó yeé (repeat many times) death PART, death PART PART 'Oh, death, oh, death...' 


\section{CONCLUSION}

\section{The Need to Document More Ethnic Languages and Musics Around the World}

In this article we have presented the results of an ethnolinguistic and ethnomusicological field research in the form of spoken and sung texts of an ethnic group which inhabits the rural parts of northwestern Ghana. After describing the community in terms of its geographical location, its language, its music and its dance, we provided brief comments and explanations of the spoken and sung texts we have painstakingly transcribed and documented in the form of a CD (Mora and Bodomo forthcoming).

In terms of how to build on this research, a further field trip is planned to do a comprehensive visual documentation of this community in the form of an anthropological film documentary. But a more pertinent and global way to build on this kind of research is for other teams of linguists, musicologists and anthropologists to undertake this kind of research among similar communities in this and other parts of the world with modern technology and techniques of recording and documentation. There is more than ever the need to document the cultural institutions, including language, music and dance, of such mainly oral cultures before they die out as a result of the rapid advance of globalization in which more dominant cultures easily drown out less dominant cultures.

\section{NOTE}

[1] The authors may be contacted at the Linguistics department, School of Humanities (first author) or the Music department, School of Humanities (second author) of The University of Hong Kong, Pokfulam Road, Hong Kong, or by e-mail at abbodomo@hku.hk, or mmora@hkucc.hku.hk

\section{ACKNOWLEDGMENTS}

This research was made possible through two grants (no. 10203082 and no. HKU7263/03H) from the University of Hong Kong Research Grants Committee. Our special thanks go to the chief, elders, and people of Kogri, in particular, Bayuo Digre, Dekongmen Bodomo, Augustina Tuodee, and A-uree Bodomo. We are also grateful to the chief and elders of Ullo, in particular, Marcelina Bongnea, Methodeus Bayor, and Seidu Issah. In Accra, we thank the Langzel Báwáá Troupe and its founder,

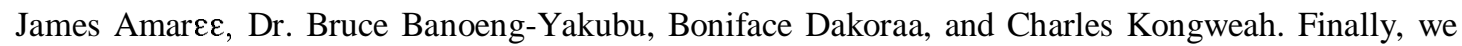

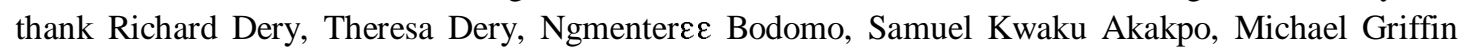
Saunders, Carmen Lee, Sophia Lee, Charles Marfo, Mary Bodomo, and Irene Suen for assistance in the research and preparation of the $\mathrm{CD}$ that was one of the outcomes of this documentation project; and Felix Bodomo, Cauvis Fung and Jeffrey Sam Siekpe for assistance and comments on the text of this journal paper. We gratefully acknowledge the many suggestions from Professor David Butler, editor of EMR, for improving this paper. His idea of an online documentation of sound clips in the form of listening examples will make the documentation project even more accessible to the public.

\section{REFERENCES}

Anttila, A., \& Bodomo, A.B. (2001). Tonal polarity in Dagaare. In Carstens, V. \& Frederick Parkinson, F. (Eds.). Trends in African Linguistics 4: Advances in African Linguistics. Trenton, NJ: Africa World Press, pp. 119-134.

Bodomo, A. B. (1997). The Structure of Dagaare. Stanford Monographs in African Linguistics, CSLI Publications.

Bodomo, A. B. (2000). Dagaare. Languages of the World's Material no. 165. Munich: Lincom Europa

Bodomo, A. B. (2004). Moore and the Gur languages. Encyclopedia of Linguistics. Fitzroy Dearborn Publishers (London: Taylor \& Francis Books, Inc.) 
Mora, M., \& Bodomo, A. B. (forthcoming). Songs and Dances of the Dagaaba of West Africa. UNESCO World Music Series.

Saighoe, F. A. K. (1984). Dagaba xylophone music of Tarkwa, Ghana: A study of situational change. Current Musicology, No. 37-38: 167-175.

Vetter, R. (2000). Beware - They are coming: Dagaare songs and dances from Nandom, Ghana; In the Time of My Fourth Great-Grandfather...: Western Sisaala Music from Lambussie, Ghana. Ethnomusicology, vol. 44, no. 2, pp. 354-356. 